\title{
Prevalence and management of anemia in pre-dialysis Malaysian patients: A hospital-based study
}

\author{
Muhammad Salman ${ }^{1 *}$, Amer Hayat Khan², Azreen Syazril Adnan ${ }^{3}$, Syed Azhar Syed Sulaiman², Khalid Hussain 5 , \\ Naureen Shehzadi ${ }^{6}$, Muhammad Islam ${ }^{7}$, Fauziah Jummaat $^{8}$ \\ ${ }^{1}$ PharmD, MSc. Doctoral Student, Discipline of Clinical Pharmacy, School of Pharmaceutical Sciences, Universiti Sains Malaysia (USM), Penang, Malaysia. Lecturer, University College of Pharmacy, University of the Punjab, \\ Lahore, Pakistan \\ ${ }^{2}$ BPharm, MPhil, PhD. Senior Lecturer, Discipline of Clinical Pharmacy, School of Pharmaceutical Sciences, USM, Penang, Malaysia \\ ${ }^{3}$ MD, MMed, FASN. Associate Professor, Chronic Kidney Disease Resource Centre, School of Medical Sciences, USM, Health Campus, Kota Bharu, Kelantan, Malaysia \\ ${ }^{4}$ BPharm, PharmD. Full Professor, Discipline of Clinical Pharmacy, School of Pharmaceutical Sciences, USM, Penang, Malaysia \\ ${ }^{5}$ BPharm, MPhil, PhD. Full Professor, University College of Pharmacy, University of the Punjab, Lahore, Pakistan \\ ${ }_{6}^{6}$ PharmD, MPhil. Doctoral Student, University College of Pharmacy, University of the Punjab, Lahore, Pakistan \\ ${ }^{7}$ BPharm, MPhil, PhD. Lecturer, University College of Pharmacy, University of the Punjab, Lahore, Pakistan \\ ${ }^{8} \mathrm{MD}$, MMed. Lecturer, Department of Gynecology and Obstetrics, School of Medical Sciences, USM, Health Campus, Kota Bharu, Kelantan, Malaysia
}

Study conducted at the Hospital Universiti Sains Malaysia, Kota Bharu, Kelantan, Malaysia

Article received: $1 / 17 / 2016$ Accepted for publication: $1 / 18 / 2016$

*Correspondence:

Address: School of Pharmaceutical Sciences, Universiti Sains Malaysia, 11800 Minden, Pulau Pinang, Malaysia msk5012@gmail.com

\section{SUMMARY}

Objective: Anemia, a common complication of chronic kidney diseases (CKD), is involved in significant cardiovascular morbidity. Therefore, the objective of our study was to investigate the prevalence and severity of anemia in pre-dialysis patients, as well as to determine the predictors of anti-anemic therapy.

Method: A retrospective, observational study was conducted on adult pre-dialysis patients receiving treatment at the Hospital Universiti Sains Malaysia from January 2009 to December 2013.

Results: A total of 615 eligible cases were included. The mean age of patients was $64.1 \pm 12.0$ years. The prevalence of anemia was $75.8 \%$, and the severity of anemia was mild in $47.7 \%$ of the patients, moderate in $32.2 \%$, and severe in $20 \%$. Based on morphological classification of anemia, $76.9 \%$ of our patients had normochromic-normocytic anemia whereas 21.8 and $1.3 \%$ had hypochromic-microcytic anemia and macrocytic anemia, respectively. Oral iron supplements were prescribed to $38.0 \%$ of the patients and none of the patients was given erythropoietin stabilizing agents (ESA) or intravenous iron preparations. In logistic regression, significant predictors of anti-anemic preparation use were decreased hemoglobin and hematocrit, and advanced stages of CKD.

Conclusion: The results of the present study suggest that the prevalence of anemia in pre-dialysis patients is higher than currently accepted and it is found to be correlated with renal function; prevalence increases with declined renal function. An earlier identification as well as appropriate management of anemia will not only have a positive impact on quality of life but also reduce hospitalizations of CKD patients due to cardiovascular events.

Keywords: anemia, antianemic therapy, chronic kidney disease, physician inertia.

\section{INTRODUCTION}

Chronic kidney disease (CKD) is a major public health problem across the world and end-stage renal disease (ESRD) is conventionally considered the most serious outcome of CKD. ${ }^{1}$ Other outcomes include complications of declined renal function, e.g. high risk of cardiovascular diseases (CVD), acute renal injury, cognitive impairment, infections, and impaired physical function..$^{2-6}$
Anemia is a very common complication of CKD and is the result of interference of erythropoietin production. However, iron and vitamin deficiencies, blood loss, reduced erythrocyte life span, chronic inflammation, and uremic milieu are also the contributing factors for anemia in CKD patients. ${ }^{7}$ Published data suggest that anemia is an independent risk factor for cardiovascular morbidity and mortality, ${ }^{8}$ and the combination of anemia and CKD is associ- 
ated with a significantly higher stroke risk. ${ }^{9} \mathrm{CVD}$ is the foremost cause of mortality in the CKD population, accounting for nearly half of the overall mortality. ${ }^{10}$ Even mild renal insufficiency is linked to a higher risk of cardiovascular events. Cardiovascular mortality in CKD population is 10 to 20 times greater than in normotensive populations. ${ }^{11}$ Untreated anemia contributes to the increased CVD burden in CKD populations.?

Timely treatment of anemia with an emphasis on raising hematocrit to at least 36\% can improve patient's quality of life, ${ }^{12}$ decrease the need of blood transfusions, ${ }^{13,14}$ improve cognitive function ${ }^{15}$ and muscle strength, ${ }^{16}$ and decrease hospitalizations and mortality. ${ }^{17,18}$ This study aimed at estimating the prevalence and severity of anemia in adult pre-dialysis patients. The secondary objective was to determine the predictors of anti-anemic therapy.

\section{Method}

This retrospective, observational study was conducted at Hospital Universiti Sains Malaysia (HUSM), Kota Bharu, Kelantan, Malaysia. All adult ( $\geq 18$ years of age) pre-dialysis patients receiving treatment at CKD Resource Centre, HUSM, from January 2009 to December 2013 were included in the study. Patients with acute renal impairment, severe hemorrhage, age $<18$ years, and dialysis patients were excluded. Data regarding demographics, laboratory investigations and medications for the treatment of anemia were gathered using a data collection form. Permission to conduct this study was obtained from Human Research Ethics Committee, Universiti Sains Malaysia, prior to data collection.

Anemia was defined as per Kidney Disease: Improving Global Outcomes (KDIGO) guidelines [hemoglobin $(\mathrm{Hb})$ $<13.0 \mathrm{~g} / \mathrm{dL}$ in males and $<12 \mathrm{~g} / \mathrm{dL}$ in females] or patient utilizing anti-anemic preparations at any $\mathrm{Hb}$ level. ${ }^{19}$ Mild anemia was defined as $\mathrm{Hb}>11 \mathrm{~g} / \mathrm{dL}$, whereas moderate and severe anemia were defined as $\mathrm{Hb} 9-11 \mathrm{~g} / \mathrm{dL}$ and $<9$ $\mathrm{g} / \mathrm{dL}$, respectively. ${ }^{20}$ Glomerular filtration rate was calculated using the Chronic Kidney Disease-Epidemiology Collaboration (CKD-EPI) Equation ${ }^{21}$ and patients were classified into the stages of CKD as per KDIGO guidelines. ${ }^{22}$

Continuous variables were presented as mean \pm standard deviation, whereas categorical variables were presented as number and percentage. Comparison of continuous variables was made by t-test and one-way ANOVA, whereas categorical variables were analyzed using chi-square test. Binary logistic regression analysis was performed with use of anti-anemic preparations as a dependent variable, controlling covariates. Covariates used for the regression model to predict use of anti-anemic preparations were age, gender, diabetes, cardiovascular disease, $\mathrm{Hb}$, serum albumin, hematocrit (HCT), and CKD stage. Data analysis was carried out using SPSS version 20.0 for Windows. A p-value $<0.05$ was considered as statistically significant.

\section{Results}

A total of 615 cases were included in the study. Patient's demographic data are shown in Table 1 . The mean age was $64.1 \pm 12.0$ years, with a preponderance of male subjects and Malay ethnic group. The most common etiology of CKD was diabetes followed by hypertension.

TABLE 1 Demographic data of the study population.

Characteristics

\begin{tabular}{ll} 
Age $($ years; mean \pm SD) & \\
Total $(n=615)$ & $64.1 \pm 12.0$ \\
CKD stage 3a $(n=74)$ & $64.9 \pm 11.3$ \\
CKD stage 3b $(n=186)$ & $66.2 \pm 10.5$ \\
CKD stage 4 $(n=240)$ & $60.5 \pm 14.0$ \\
CKD stage 5 $(n=115)$ & \\
\hline Gender & $394(64.1 \%)$ \\
Male & $221(35.9 \%)$ \\
Female & \\
\hline Ethnicity & $583(94.8 \%)$ \\
Malay & $26(4.2 \%)$ \\
Chinese & $3(0.5 \%)$ \\
Indian & $3(0.5 \%)$ \\
Other & \\
\hline Etiology & $264(42.9 \%)$ \\
Diabetes & $177(28.8 \%)$ \\
Hypertension & $24(3.9 \%)$ \\
Glomerular disease & $147(23.9 \%)$ \\
Other & $14.4 \pm 8.1$ \\
\hline Serum urea (mmol/L; mean $\pm S D)$ & $256.8 \pm 179.0$ \\
\hline Serum creatinine $(\boldsymbol{\mu m o l} / \mathrm{L} ;$ mean $\pm S D)$ & $27.8 \pm 13.5$ \\
\hline eGFR (mL/min/1.73 $\mathbf{m}^{2} ;$ mean $\left.\pm S D\right)$ & \\
\hline
\end{tabular}

CKD: chronic kidney disease; SD: standard deviation; eGFR: estimated glomerular filtration rate.

As presented in Table 2, the prevalence of anemia was $75.8 \%$, with significant increase in percentage of anemic patients by declining kidney function $(p<0.001)$. The percentage of patients with mild, moderate and severe anemia was around $47.7,32.2$ and $20.0 \%$, respectively, with a higher percentage of patients with moderate and severe anemia by decreasing renal function. The morphological classes of anemia in our patients were hypochromic-microcytic anemia $(21.8 \%)$, normochromic-normocytic anemia $(76.9 \%)$ and macrocytic anemia (1.3\%). 


\begin{tabular}{|c|c|c|c|c|c|c|}
\hline Characteristics & $\begin{array}{l}\text { Total } \\
(n=615)\end{array}$ & $\begin{array}{l}\text { CKD stage } 3 a \\
(n=74)\end{array}$ & $\begin{array}{l}\text { CKD stage } 3 b \\
(n=186)\end{array}$ & $\begin{array}{l}\text { CKD stage } 4 \\
(n=240)\end{array}$ & $\begin{array}{l}\text { CKD stage } 5 \\
(n=115)\end{array}$ & p-value \\
\hline Anemia (\%) & 75.8 & 41.9 & 63.4 & 85.4 & 97.4 & $<0.001$ \\
\hline \multicolumn{7}{|l|}{ Severity of anemia (\%) } \\
\hline Mild & 47.7 & 75.7 & 65.4 & 42.5 & 12.2 & $<0.001$ \\
\hline Moderate & 32.2 & 20.3 & 26.5 & 37.5 & 38.3 & \\
\hline Severe & 20.0 & 4.1 & 8.1 & 20.0 & 49.6 & \\
\hline \multicolumn{7}{|l|}{ Morphological types (\%) } \\
\hline Microcytic anemia & 21.8 & 18.9 & 22.7 & 21.7 & 22.6 & 0.78 \\
\hline Normocytic anemia & 76.9 & 78.4 & 75.7 & 77.1 & 77.4 & \\
\hline Macrocytic anemia & 1.3 & 2.7 & 1.6 & 1.3 & - & \\
\hline $\mathrm{Hb}(\mathrm{g} / \mathrm{dL} ;$ mean $\pm \mathrm{SD})$ & $10.9 \pm 2.4$ & $12.8 \pm 2.1$ & $11.8 \pm 2.3$ & $10.6 \pm 2.0$ & $8.9 \pm 1.8$ & $<0.001$ \\
\hline HCT (\%; mean \pm SD) & $32.8 \pm 6.8$ & $37.9 \pm 5.7$ & $35.4 \pm 6.3$ & $31.9 \pm 5.9$ & $27.1 \pm 5.4$ & $<0.001$ \\
\hline $\mathrm{RBC}\left(\times 10^{12} / \mathrm{L} ;\right.$ mean $\left.\pm \mathrm{SD}\right)$ & $3.87 \pm 0.80$ & $4.43 \pm 0.67$ & $4.19 \pm 0.74$ & $3.76 \pm 0.70$ & $3.22 \pm 0.65$ & $<0.001$ \\
\hline MCV (Fl; mean \pm SD) & $84.9 \pm 7.4$ & $86.2 \pm 7.2$ & $84.5 \pm 7.3$ & $85.1 \pm 7.5$ & $84.4 \pm 7.3$ & 0.33 \\
\hline $\mathrm{MCH}(\mathrm{Pg} ;$ mean $\pm \mathrm{SD})$ & $28.3 \pm 2.7$ & $28.9 \pm 2.5$ & $28.3 \pm 2.7$ & $28.3 \pm 2.7$ & $27.8 \pm 2.6$ & 0.047 \\
\hline $\mathrm{MCHC}(\mathrm{g} / \mathrm{dL} ;$ mean $\pm \mathrm{SD})$ & $33.2 \pm 1.6$ & $33.6 \pm 1.3$ & $33.3 \pm 1.8$ & $33.2 \pm 1.7$ & $33.0 \pm 1.3$ & 0.046 \\
\hline
\end{tabular}

CKD: chronic kidney disease; Hb: hemoglobin; HCT: hematocrit; RBC: red blood cells; MCV: mean corpuscular volume; MCH: mean corpuscular hemoglobin; MCHC: mean corpuscular hemoglobin concentration; SD: standard deviation.

The prevalence of mild, moderate, and severe anemia by gender is presented in Table 3. There were significantly greater anemic female CKD patients as compared to male patients $(\mathrm{p}=0.001)$. Moreover, prevalence of mild anemia was significantly greater in male than in female patients. But the prevalence of female CKD patients suffering from moderate and severe anemia was significantly higher as compared to male subjects. There was a significantly lower level of Hb, HCT and erythrocytes in females as compared to male patients.

TABLE 3 Gender-based comparison of anemia

\section{parameters.}

\begin{tabular}{llll} 
Parameters & $\begin{array}{l}\text { Male } \\
(\mathbf{n = 3 9 4})\end{array}$ & $\begin{array}{l}\text { Female } \\
(\mathbf{n}=\mathbf{2 2 1})\end{array}$ & p-value \\
& 71.6 & 83.3 & 0.001 \\
\hline Anemia (\%) & & & \\
\hline Severity of anemia (\%) & 53.9 & 36.7 & $<0.001$ \\
Mild & 31.0 & 34.4 & \\
Moderate & 15.0 & 29.0 & \\
Severe & $34.0 \pm 6.8$ & $30.7 \pm 6.3$ & $<0.001$ \\
\hline HCT (\%; mean \pm SD) & $4.01 \pm 0.78$ & $3.63 \pm 0.79$ & $<0.001$ \\
\hline RBC (x 1012/L; mean $\pm S D)$ & $85.0 \pm 7.0$ & $84.8 \pm 8.0$ & 0.053 \\
\hline MCV (Fl; mean $\pm S D)$ & $28.4 \pm 2.6$ & $28.2 \pm 2.8$ & 0.28 \\
\hline MCH (Pg; mean $\pm S D)$ & $33.3 \pm 1.6$ & $33.2 \pm 1.7$ & 0.95 \\
\hline MCHC (g/dL; mean $\pm S D)$ & & &
\end{tabular}

$\mathrm{Hb}$ : hemoglobin; HCT: hematocrit; RBC: red blood cells; MCV: mean corpuscular volume; $\mathrm{MCH}$ : mean corpuscular hemoglobin; MCHC: mean corpuscular hemoglobin concentration; SD: standard deviation.
Anti-anemic preparations were prescribed for only 38.0\% of the patients. Underutilization of erythropoietin stabilizing agents was apparent as none of the patients received these agents for the management of anemia. The predictors of oral anti-anemic therapy use are shown in Table 4. The logistic regression model was statistically significant, $\chi^{2}$ $(10)=196.086, \mathrm{p}<0.001$. The model explained $37.1 \%$ (Nagelkerke $\mathrm{R}^{2}$ ) of the variance in use of anti-anemic preparations and correctly classified $75.6 \%$ of cases. Result of Hosmer and Lemeshow test for goodness-of-fit indicated that our model predicts values not significantly different than what we observed, $\chi^{2}(8)=7.320, p=0.50$. Patients with $\mathrm{Hb} 9-11 \mathrm{~g} / \mathrm{dL}$ were 2.14 times more likely to be prescribed anti-anemic preparations, holding all other independent variables constant. Moreover, patients with $\mathrm{Hb}<9 \mathrm{~g} / \mathrm{dL}$ were 2.90 times more likely to be given anti-anemic therapy. Decreased HCT level was associated with 2.65 times odds of anti-anemic therapy use. Moreover, the deteriorating kidney function (increased severity of CKD) was also a positive predictor of oral anti-anemic preparations use.

\section{Discussion}

Our main findings in this study showed that prevalence of anemia increased significantly with deteriorating renal function. Furthermore, decreased $\mathrm{Hb}$ and HCT, as well as advanced stages of CKD were the significant predictors of anti-anemic agents use in pre-dialysis patients at a Malaysian tertiary care hospital. 
TABLE 4 Predictors of use of oral anti-anemic preparations.

\begin{tabular}{|c|c|c|c|c|}
\hline \multirow[t]{2}{*}{ Variables } & \multicolumn{2}{|l|}{ Univariate } & \multicolumn{2}{|l|}{ Multivariate } \\
\hline & OR (95CI) & $\mathrm{p}$-value & OR (95CI) & $\mathrm{p}$-value \\
\hline Age & $0.99(0.98-1.00)$ & 0.17 & & \\
\hline \multicolumn{5}{|l|}{ Gender } \\
\hline Male & 1.00 (Reference) & - & & \\
\hline Female & $1.65(1.18-2.31)$ & 0.004 & & \\
\hline Diabetes & $0.97(0.68-1.37)$ & 0.85 & & \\
\hline CVD & $0.636(0.45-0.90)$ & 0.010 & & \\
\hline \multicolumn{5}{|l|}{$\mathrm{Hb}(\mathrm{g} / \mathrm{dl})$} \\
\hline$>11$ & 1.00 (Reference) & - & 1.00 (Reference) & - \\
\hline $9-11$ & $4.61(3.04-7.00)$ & $<0.001$ & $2.14(1.28-3.61)$ & 0.013 \\
\hline$<9$ & $15.15(9.09-25.26)$ & $<0.001$ & $2.90(1.25-6.73)$ & 0.004 \\
\hline \multicolumn{5}{|c|}{ Albumin $(g / L)$} \\
\hline$>44$ & 1.00 (Reference) & - & & \\
\hline $38-44$ & $0.86(0.43-1.70)$ & 0.66 & & \\
\hline$\leq 37$ & $2.14(1.09-4.19)$ & 0.027 & & \\
\hline \multicolumn{5}{|c|}{ Hematocrit (\%) } \\
\hline$>30$ & 1.00 (Reference) & - & 1.00 (Reference) & - \\
\hline$<30$ & $7.93(5.44-11.56)$ & $<0.001$ & $2.65(1.43-4.92)$ & 0.002 \\
\hline \multicolumn{5}{|c|}{ CKD severity } \\
\hline Stage $3 a$ & 1.00 (Reference) & - & 1.00 (Reference) & - \\
\hline Stage $3 b$ & $1.67(0.76-3.68)$ & 0.20 & $1.36(0.60-1.37)$ & 0.47 \\
\hline Stage 4 & $6.11(2.91-12.83)$ & $<0.001$ & $4.08(1.86-8.98)$ & $<0.001$ \\
\hline Stage 5 & $16.51(7.40-36.82)$ & $<0.001$ & $6.07(2.54-14.52)$ & $<0.001$ \\
\hline
\end{tabular}

CKD: chronic kidney disease; CVD: cardiovascular disease; OR: odds ratio; $\mathrm{Cl}$ : confidence interval; $\mathrm{Hb}$ : hemoglobin.

The mean age of the patients in this study was similar to that reported in a previous study. ${ }^{23}$ There was a predominance of male subjects, which was similar to the results of previous reports. ${ }^{20,23}$ The study population included mostly Malays, since our setting was the northeastern peninsular Malaysia, more specifically the States of Kelantan, Terengganu and Pahang. There is a wide variation in the prevalence of anemia and its severity in CKD patients. In the present study, the prevalence of anemia was $75.8 \%$. By contrast, Martinez-Castellao et al. reported a 51.3\% prevalence of anemia in their Spanish cohort of CKD stage 3 and 4 patients. ${ }^{20}$ Likewise, a study conducted by Poudel et al. ${ }^{24}$ reported that the prevalence of anemia was $47.85 \%$ in Nepali CKD patients. In both of these studies, the findings were lower than our results because most of our CKD cohort had advanced stages of CKD. We found that prevalence of anemia increased with progressively deteriorating renal function. Regarding the severity of anemia, majority of the patients in our study had mild anemia followed by moderate anemia. Conversely, most of the patients in a previous study had moderate anemia followed by mild anemia. ${ }^{25}$ We also observed that the percentage of CKD stage 5 patients with mild anemia was significantly lower than in the early stages, whereas the percentage of patients with CKD stage 5 having moderate and severe anemia were significantly higher as compared to other CKD stages. These findings reflect that severity of anemia increases with declining renal function, which can be attributable to various factors associated with the development of anemia in CKD, such as erythropoietin insufficiency, iron and vitamin deficiency, malnutrition, inflammation, platelet dysfunction, reduced red blood cell survival, and hemolysis. ${ }^{7}$ Similar to the findings of a previous study, ${ }^{24}$ we also found that mean level of $\mathrm{Hb}$, red blood cells, mean corpuscular hemoglobin and mean corpuscular hemoglobin concentration were significantly decreased by deteriorating renal function. This considerable decrease could be another cause of a higher prevalence of anemia by deteriorating kidney function. Levels of $\mathrm{Hb}, \mathrm{HCT}$, and red blood cells were significantly lower in female CKD patients than in male patients. Findings from a previous study conducted on ESRD patients also revealed that Hb-level was significantly lower in females as compared to male patients. ${ }^{26}$ Most of the patients in the current study had 
normochromic-normocytic anemia followed by hypochromic-microcytic anemia, which was comparable to the findings of an earlier study. ${ }^{25}$

We observed a mismatch between the number of patients with anemia and the number of patients treated for anemia. Nearly half of the patients with anemia (37.8\%) were not being treated with an anti-anemic agent according to their medical charts. Probable explanations for this finding are clinical inertia or a higher frequency of patients with mild anemia using vitamins (vitamin B complex). Nonetheless, the use of oral iron therapy in this study was greater than previously reported. ${ }^{23}$ Ferrous fumarate (325 mg once daily) and folic acid ( $5 \mathrm{mg}$ once daily) were the predominantly prescribed oral iron supplement combination for the treatment of anemia in our cohort. Underutilization of erythropoietin stabilizing agents in the current study might also be attributable to physician inertia or its prohibitive cost. Our study proposes that there is room for substantial improvement in terms of anemia control. Bailie et al. ${ }^{23}$ reported that the positive predictors of iron use in pre-dialysis patients were Caucasians [odds ratio $(\mathrm{OR})=2.6$ ] and diabetics $(\mathrm{OR}=2.1)$. Contrary to these findings, we found that the significant predictors of anti-anemic therapy prescribed were decreased HCT and Hb level, and increased severity of CKD.

This study was carried out in a single Malaysian tertiary care hospital and the vast majority of the patients were Bumiputera (Malay ethnicity) from the northeastern peninsular region. Therefore, the findings may not be representative of the multiethnic Malaysian population. This study indicates the need to conduct a brief survey among physicians, enquiring reasons for prescribing or not prescribing erythropoietin stabilizing agents. Nevertheless, this study offers valuable information regarding the prevalence, severity and treatment of anemia in Malaysian pre-dialysis patients.

\section{Conclusion}

Prevalence of anemia is high among pre-dialysis Malaysian patients at this tertiary care hospital, and is correlated with declining renal function. Earlier identification as well as proper management of anemia may not only have a positive impact on the patient's quality of life but also reduce hospitalization of CKD patients due to CVD.

\section{ACKNOWLEDGMENTS}

Authors are very grateful to Ms. Nurul Jannah Ambak (Unit of Biostatistics and Research Methodology, School of Medical Sciences, Universiti Sains Malaysia) for assisting in the statistical analysis. Moreover, authors are also thankful for the assistance of the staff of the CKD Resource Centre, Kota Bharu, Kelantan, Malaysia, especially Ms. Cheiok Chia Lee and Mr. Nik Zamli.

\section{Resumo}

Anemia em pacientes pré-diálise: prevalência, gravidade, manejo

Objetivo: anemia é uma complicação comum de doenças renais crônicas (DRC) e está significativamente envolvida na morbidade cardiovascular. O objetivo de nosso estudo foi investigar a prevalência e a gravidade da anemia em pacientes adultos pré-diálise, bem como determinar fatores preditores da terapia antianêmica.

Método: estudo retrospectivo observacional foi realizado em pacientes pré-diálise adultos que recebiam tratamento no Hospital Universiti Sains Malaysia de janeiro de 2009 a dezembro de 2013.

Resultados: ao todo, 615 casos elegíveis foram incluídos. A idade média dos pacientes foi de $64,1 \pm 12,0$ anos. A prevalência de anemia foi de $75,8 \%$, e a gravidade da anemia foi considerada leve em $47,7 \%$, moderada em $32,2 \%$ e grave em $20 \%$ dos pacientes. Com base nas características morfológicas da anemia, os pacientes foram classificados em anemia normocrômica normocítica $(76,9 \%)$, anemia hipocrômica microcítica $(21,8 \%)$ e anemia macrocítica $(1,3 \%)$. Suplementos de ferro oral foram prescritos para $38 \%$ dos pacientes e a nenhum dos pacientes foram dados eritropoietina, agentes estabilizadores (ESA) e preparações de ferro por via intravenosa. Na regressão logística, os preditores significativos de utilização da preparação antianêmica foram diminuição da hemoglobina e do hematócrito e estágios avançados da DRC.

Conclusão: os resultados do presente estudo sugerem que a prevalência de anemia em pacientes pré-diálise é maior do que o atualmente aceito e está associado com a função renal; a prevalência aumenta com a diminuição da função renal. A identificação precoce e o manejo adequado da anemia não só terão um impacto positivo na qualidade de vida, mas também reduzirão internações de pacientes com DRC decorrentes de eventos cardiovasculares.

Palavras-chave: anemia, terapia antianêmica, doença renal crônica, inércia do médico.

\section{References}

1. Levey AS, Coresh J. Chronic kidney disease. Lancet. 2012; 379(9811):165-80.

2. Hailpern SM, Melamed ML, Cohen HW, Hostetter TH. Moderate chronic kidney disease and cognitive function in adults 20 to 59 years of age: Third 
National Health and Nutrition Examination Survey (NHANES III). J Am Soc Nephrol. 2007; 18(7):2205-13.

3. Hsu CY, Ordoñez JD, Chertow GM, Fan D, McCulloch CE, Go AS. The risk of acute renal failure in patients with chronic kidney disease. Kidney Int. 2008; 74(1):101-7.

4. James MT, Quan H, Tonelli M, Manns BJ, Faris P, Laupland KB, et al. CKD and risk of hospitalization and death with pneumonia. Am J Kidney Dis. 2009; 54(1):24-32.

5. James MT, Hemmelgarn BR, Wiebe N, Pannu N, Manns BJ, Klarenbach SW, et al. Glomerular filtration rate, proteinuria, and the incidence and consequences of acute kidney injury: a cohort study. Lancet. 2010; 376(9758):2096-103.

6. Wilhelm-Leen ER, Hall YN, Tamura MK, Chertow GM. Frailty and chronic kidney disease: the third national health and nutrition evaluation survey. Am J Med. 2009; 122(7):664-71.

7. Nurko S. Anemia in chronic kidney disease: causes, diagnosis, treatment. Clev Clin J Med. 2006; 73(3):289-97.

8. Sarnak MJ, Tighiouart H, Manjunath G, MacLeod B, Griffith J, Salem D, et al. Anemia as a risk factor for cardiovascular disease in The Atherosclerosis Risk in Communities (ARIC) study. J Am Coll Cardiol. 2002; 40(1):27-33.

9. Abramson JL, Jurkovitz CT, Vaccarino V, Weintraub WS, McClellan W. Chronic kidney disease, anemia, and incident stroke in a middle-aged, communitybased population: the ARIC Study. Kidney Int. 2003; 64(2):610-5.

10. Haynes RJ, Winearls CG. Chronic kidney disease. Surgery (Oxford). 2010; 28(11):525-9.

11. Foley RN, Parfrey PS, Sarnak MJ. Epidemiology of cardiovascular disease in chronic renal disease. J Am Soc Nephrol. 1998; 9(12 Suppl):S16-23.

12. Moreno F, Sanz-Guajardo D, López-Gómez JM, Jofre R, Valderrábano F. Increasing the hematocrit has a beneficial effect on quality of life and is safe in selected hemodialysis patients. Spanish Cooperative Renal Patients Quality of Life Study Group of the Spanish Society of Nephrology. J Am Soc Nephrol. 2000; 11(2):335-42.

13. Eschbach JW, Adamson JW. Iron overload in renal failure patients: changes since the introduction of erythropoietin therapy. Kidney Int Suppl. 1999; 69:S35-43.

14. Eschbach JW, Abdulhadi MH, Browne JK, Delano BG, Downing MR, Egrie JC, et al. Recombinant human erythropoietin in anemic patients with end- stage renal disease. Results of a phase III multicenter clinical trial. Ann Intern Med. 1989; 111(12):992-1000.

15. Marsh JT, Brown WS, Wolcott D, Carr CR, Harper R, Schweitzer SV, et al $\mathrm{rHuEPO}$ treatment improves brain and cognitive function of anemic dialysis patients. Kidney Int. 1991; 39(1):155-63.

16. Robertson HT, Haley NR, Guthrie M, Cardenas D, Eschbach JW, Adamson JW. Recombinant erythropoietin improves exercise capacity in anemic hemodialysis patients. Am J Kidney Dis. 1990; 15(4):325-32.

17. Ma JZ, Ebben J, Xia H, Collins AJ. Hematocrit level and associated mortality in hemodialysis patients. J Am Soc Nephrol. 1999; 10(3):610-9.

18. Xia H, Ebben J, Ma JZ, Collins AJ. Hematocrit levels and hospitalization risks in hemodialysis patients. J Am Soc Nephrol. 1999; 10(6):1309-16.

19. Kidney Disease: Improving Global Outcomes (KDIGO) Anemia Work Group. KDIGO Clinical Practice Guideline for Anemia in Chronic Kidney Disease. Kidney Int Supplements. 2012; 2(4):279-335.

20. Martínez-Castelao A, Górriz JL, Portolés JM, De Alvaro F, Cases A, Luño J, et al. Baseline characteristics of patients with chronic kidney disease stage 3 and stage 4 in Spain: the MERENA observational cohort study. BMC Nephrol. 2011; $12: 53$.

21. Levey AS, Stevens LA, Schmid CH, Zhang YL, Castro 3rd AF, Feldman HI, et al.; CKD-EPI (Chronic Kidney Disease Epidemiology Collaboration). A new equation to estimate glomerular filtration rate. Ann Intern Med. 2009; 150(9):604-12.

22. Kidney Disease: Improving Global Outcomes (KDIGO) CKD Work Group. KDIGO 2012 Clinical Practice Guideline for the Evaluation and Management of Chronic Kidney Disease. Kidney Int Supplements. 2013; 3(1):1-150.

23. Bailie GR, Eisele G, Liu L, Roys E, Kiser M, Finkelstein F, et al. Patterns of medication use in the RRI-CKD study: focus on medications with cardiovascular effects. Nephrol Dial Transplant. 2005; 20(6):1110-5.

24. Poudel B, Yadav BK, Jha B, Raut KB, Pandeya DR. Prevalence and association of anemia with CKD: a hospital based cross-sectional study from Nepal. Biomedical Res. 2013; 24(1):99-103

25. Afshar R, Sanavi S, Salimi J, Ahmadzadeh M. Hematological profile of chronic kidney disease (CKD) patients in Iran, in pre-dialysis stages and after initiation of hemodialysis. Saudi J Kidney Dis Transplant. 2010; 21(2):368-71.

26. Al-Ageel NA, Al-Aqeel SA, Abanmy NO, Alwakeel JS, Sabry A, Alsaran KA Appropriateness of anemia management in hemodialysis patients. Saudi Pharm J. 2012; 20(1):85-91. 